\title{
Modulatory antimicrobial activity of Piper arboreum extracts
}

\author{
Saulo R. Tintino ${ }^{1}$, Celestina E. S. Souza ${ }^{1}$, Gláucia M. M. Guedes ${ }^{1}$, \\ Jaqueline I. V. Costa ${ }^{2}$, Francisco M. Duarte ${ }^{2}$, Maria Célia O. Chaves ${ }^{2}$, \\ Viviane A. Silvi ${ }^{2}$, Hilzeth L. F. PessôA ${ }^{2}$, Micheline A. Lima ${ }^{2}$, \\ Carlos A. Garcia ${ }^{2}$, Henrique D. M. Coutinho ${ }^{1,3^{*}}$ \\ ${ }^{1}$ Laboratory of Microbiology and Molecular Biology, Regional University of Cariri, \\ Rua Cel. Antonio Luis 1161, Pimenta, 63105-000 Crato, Ceará State, Brazil. \\ ${ }^{2}$ Laboratory of Pharmaceutical Technology, Federal University of Paraíba, 58051-900, \\ João Pessoa, Paraíba state, Brazil. \\ ${ }^{3}$ Chemical Biological Department, Regional University of Cariri, \\ Rua Cel. Antonio Luis 1161, Pimenta, 63105-000 Crato, Ceará State, Brazil
}

\begin{abstract}
The side effects of certain antibiotics have been a recent dilemma in the medical arena. Due this fact, the necessity of natural product discovery could provide important indications against several pharmacological targets and combat many infectious agents. Piper arboreum Aub. (Piperaceae) has been used by Brazilian traditional communities against several illnesses including rheumatism, bronchitis, sexually transmitted diseases and complaints of the urinary tract. Medicinal plants are a source of several remedies used in clinical practice to combat microbial infections. In this study, ethanol extract and fractions of Piper arboreum leaves were used to assay antimicrobial and modulatory activity. The minimum inhibitory concentration (MIC) was determined using microdilution method of ethanol extract and fractions from the leaves of $P$. arboreum ranging between 8 and $1024 \mu \mathrm{g} \mathrm{mL}^{-1}$. The capacity of these natural products to enhance the activity of antibiotic and antifungal drugs was also assayed. In these tests, natural products were combined with drugs. The natural products assayed did not demonstrate any clinically relevant antimicrobial activity (MIC $\geq 1024 \mu \mathrm{g} \mathrm{mL}^{-1}$ ). However, the modulation of antibiotic activity assay observed a synergistic activity of natural products combined with antifungal (such as nystatin and amphotericin B) and antibiotic drugs (such as amikacin, gentamicin and kanamycin). According to these results, these natural products can be an interesting alternative not only to combat infectious diseases caused by bacteria or fungi, but also to combat enhanced resistance of microorganisms to antibiotic and antifungal drugs.
\end{abstract}

* Corresponding author, e-mail: hdmcoutinho@gmail.com

Copyright ${ }^{\circledR} 2014$ by Acta Botanica Croatica, the Faculty of Science, University of Zagreb. All rights reserved. 
Tintino S. R., Souza C. E. S., Guedes G. M. M., Costa J. I. V., Duarte F. M. et al.

Keywords: antimicrobial activity, synergism, Piper arboretum, Staphylococcus aureus, Escherichia coli, Candida

Abbreviations: ATCC - American type culture collection; MIC - minimum inhibitory concentration

\section{Introduction}

The genus Piper (Piperaceae) presents almost 1,000 species, distributed mainly in the tropical and subtropical regions of Asia and America. Plants from this genus are used for commercial and medicinal purposes (NuNES et al. 2007) and demonstrate several biological activities (RUIZ and ROQUE 2009). Antibacterial and trypanocidal activities have been reported for Piper arboreum Aub. and this plant is used by traditional communities in Brazil in the form of a decoct against rheumatism, bronchitis, and sexually transmitted diseases (Agra et al. 2007, RAmos and Kato 2009, REgAsini et al. 2009).

The World Health Organization (WHO 1998) defines a medicinal plant as any plant that contains any active compounds that can be used for therapeutic or chemical purposes. Substances produced by plants are their defence mechanism against insects, herbivores, and phytopathogenic microorganisms (GotLIEB 1981). Some researchers have named these phytocompounds »antibiotic like-substances «(GEISMANN 1963). The use of plant extracts as antimicrobial agents represents a low risk for the development of resistance by the microorganisms because these products are composed of several phytocompounds of different groups (DAFERERA et al. 2003).

Concerning resistance to antibiotics, many researchers have expressed their opinion that natural products from plants could be interesting alternatives (DANCER 2001, NOSTRO et al. 2004, Coutinho et al. 2005, GeORgOPAPADAKOU 2005). Several plant extracts and phytochemicals are known for their antimicrobial properties. Many studies have been conducted in different countries to demonstrate such activities (SALVAGNINI et al. 2008, SIMÕES et al. 2008, Silva et al. 2008).

The Staphylococcus genus is found in skin and mucosal microbiota of animals and birds. Some Staphylococcus species are etiological agents of many animal and human infections (Nostro et al. 2004, CoutinHo et al. 2009a, b). Staphylococcus aureus, S. epidermidis, S. saprophyticus and $S$. haemolyticus are the most important etiological agents of community and nosocomial human infections. Besides, this bacterium is responsible for different types of intoxications, being the most common etiological agent of infections on different tissues and/or organs (e.g. furuncle, carbuncle, abscess, myocarditis, endocarditis, pneumonia, meningitis, bacterial arthritis) (VERHOEFF et al. 1999). Escherichia coli is one of the most important human infectious agents. This bacterium is an enterotoxin producer and the causal agents of diarrhoea outbreaks (KoNOWALCHUK et al. 1977, ScOTLAND et al. 1980) and urinary tract infections (HuGHES et al. 1982).

Candidiasis is the most frequent mycosis caused by opportunistic fungi. The main species associated with this disease are Candida albicans, C. tropicalis, C. parapsilosis, C. glabrata and $C$. krusei (CoutinHo 2009). These yeasts are found in skin and in mucosal microbiota, becoming pathogenic in patients with immunodeficiency or immunosuppression (DIGNANI et al. 2003). 
Many plants have been evaluated not only for direct antimicrobial activity but also as resistance-modifying agents (GIBBONS 2004). Several chemical compounds, synthetic or from natural sources, have demonstrated a direct activity against many species of bacteria, enhancing the activity of a specific antibiotic, reversing the natural resistance of bacteria to a specific antibiotic, causing the elimination of plasmids and inhibiting the active efflux of antibiotics through the plasma membrane (COUTINHO et al. 2009a, b). The potentiation of antibiotic activity or the reversal of antibiotic resistance allows the classification of these compounds as modifiers of antibiotic activity (COUTINHO et al. 2009a).

The aim of this work was to evaluate the antimicrobial and modulatory activity of ethanol extract and fractions of Piper arboreum associated with antibiotic and antifungal drugs against multiresistant bacteria and fungi.

\section{Materials and methods}

\section{Microbial strains}

The bacteria used in the minimum inhibitory concentration assay were the strains of $E$. coli ATCC25923 and S. aureus ATCC10536. In the antifungal assays, the strains of Candida albicans ATCC40006, C. krusei ATCC2538 and C. tropicalis ATCC40042 were used. To evaluate the modulatory activity of the ethanol extract and fractions the multiresistant bacterial strains isolated from clinical environments: E. coli 27 and S. aureus 358 with the resistance profile were used (Tab. 1). All strains were obtained from the Laboratory of Clinical Mycology - Universida de Federal da Paraíba.

Tab. 1. Bacterial source and antibiotic resistance profile.

\begin{tabular}{lcc}
\hline Bacteria & Source & Antibiotic resistance \\
\hline Escherichia coli 27 & Surgical wound & Ast, Ax, Ami, Amox, Ca, Cfc, Cf, Caz, \\
Cip, Clo, Im, Can, Szt, Tet, Tob \\
Escherichia coli ATCC10536 & - & \\
Staphylococcus aureus ATCC25923 & - & \\
Staphylococcus aureus 358 & Surgical wound & Oxa, Gen, Tob, Ami, Can, Neo, \\
\end{tabular}

Ami - amicilina; Amox - amoxillin, Amp - ampicillin; Ast - aztreonam; Ax - amoxacillin; But butirosina; $\mathrm{Ca}$ - cefadroxil; Can - canamycin; Caz - ceftazinidima; $\mathrm{Cfc}$ - cefaclor; $\mathrm{Cf}$ - cephalothin; Cip - ciprofloxacin; Clo - chloramphenicol; Com - cefepime; Ctz - ceftazidime; Gen - gentamicin; Imi - imipenem; Lev - levofloxacin; Mer - merpenem; Neo - neomycin; Net - netilmicin; Oxa oxacillin; Sis - sisomicin; Szt - sulfametrim; Tet - tetracycline; Tob - tobramycin; Para - paramomicina; Ptz - piperacilina-tazobactam

\section{Plant material}

Stems of Piper arboreum were collected in March/2010 in the Gaiambira reserve, Bananeiras County, Paraíba State (Brazil). The plant material was identified by Prof. Carlos Alberto Garcia and a voucher (C. A. Garcia 205) was deposited in the Education and Health Center Herbarium, Universida de Federal de Campina Grande. The leaves of Piper arbo- 
reum, after collection, were dried at $40{ }^{\circ} \mathrm{C}$ by 72 hours and powdered, obtaining $1.5 \mathrm{~kg}$. The powdered material was extracted by maceration using $1 \mathrm{~L}$ of $95 \%(\mathrm{v} / \mathrm{v})$ methanol as solvent at room temperature by three days, this process being repeated five times. The solution was then filtered and concentrated under vacuum in a rotary evaporator under $60{ }^{\circ} \mathrm{C}$ and 760 $\mathrm{mm} / \mathrm{Hg}$ of temperature and pressure, respectively. This amount of powdered material yielded $350 \mathrm{~g}$ of ethanol extract.

The ethanol extract from the leaves (50 g) of Piper arboreum was dissolved in a mixture of EtOH: $\mathrm{H}_{2} \mathrm{O}$ (7:3), generating a hydroalcohol solution which was submitted to a liquid/ liquid partition using the following solvents: hexane, dichloromethane and ethyl acetate. The obtained solutions were mixed with sodium sulphate anhydrous $\left(\mathrm{Na}_{2} \mathrm{SO}_{4}\right)$ and filtered. After this process, the solutions were concentrated using a rotary vacuum evaporator at temperatures below $50{ }^{\circ} \mathrm{C}$, yielding the following fractions: hexane fraction $(3 \mathrm{~g})$, dichloromethane fraction $(3.5 \mathrm{~g})$ and ethyl acetate fraction $(9 \mathrm{~g})$.

\section{Drugs}

The drugs used in the tests were the aminoglycosides kanamycin, amikacin, neomycin and gentamicin, and the antifungals mebendazole, amphotericin B, nystatin and benzoylmetronidazole (Sigma Co., St. Louis, USA). All drugs were diluted in sterile water.

\section{Minimum inhibitory concentration}

The broth microdilution method was used in order to determine minimum inhibitory concentration (MIC). The ethanol extract and fractions were dissolved using dimethylsulfoxide and diluted to $1024 \mu \mathrm{g} \mathrm{mL}^{-1}$ using sterile distilled water. The bacterial inoculum was diluted using brain heart infusion broth to a final concentration of $10^{5}$ colony forming units per $\mathrm{mL}$. Each inoculum $(100 \mu \mathrm{L})$ was distributed in each well of a microtiter 96 wells plate and then submitted to a twofold serial dilution using $100 \mu \mathrm{L}$ of the ethanol extract, with concentrations ranging between 8 and $1024 \mu \mathrm{g} \mathrm{mL}^{-1}$. The plates were incubated for 24 hours at $35^{\circ} \mathrm{C}$ (JAVADPOUR et al. 1996). Bacterial MIC was determined using resazurin, with blue changing to red indicating bacterial growth. The fungal MIC was determined by turbidity, observing the growth of fungal strains. The MIC was defined as the lowest concentration in which no growth can be observed, according to CLSI (2008). Positive controls of growth were performed using the culture medium with the microbial inoculum.

\section{Drug modulation test}

To observe how the ethanol extract and fractions affect the action of antimicrobial drugs against the assayed strains, the method proposed by CoutinHo et al. (2008) was used. The ethanol extracts and fractions were tested using a sub-inhibitory concentration (MIC/8 = $128 \mu \mathrm{g} \mathrm{mL}^{-1}$ ). A sample with $100 \mu \mathrm{L}$ of the solution containing brain heart infusion broth, the microbial inoculums and the extract or fractions was placed in each well. After this, 100 $\mu \mathrm{L}$ of the antimicrobial drug was mixed in the first well, following the twofold dilution. Concentrations of aminoglycosides and antifungals ranged between 5000 and $2.44 \mu \mathrm{g} \mathrm{mL}^{-1}$ and 1024 and $2 \mu \mathrm{g} \mathrm{mL}^{-1}$, respectively. The assays were performed in triplicate. 


\section{Results and discussion}

The MIC results of the extract and fractions alone and combined with antifungals are demonstrated in the table 2. Against all fungal strains assayed, the MIC observed was $\geq$ $1024 \mu \mathrm{g} \mathrm{mL}^{-1}$, these results not being clinically relevant. The same results were observed by REGASINI et al. (2009). However, when the antifungal drugs were associated with the extract and fractions, a synergistic activity was observed against $C$. krusei, enhancing the antifungal drug activity. The MIC results of the natural products alone and combined with amino-

Tab. 2. Minimum inhibitory concentration (MIC) of antifungal drugs alone and associated with extract and fractions of Piper arboreum against C. albicans, C. krusei and C. tropicalis $\left(\mu \mathrm{g} \mathrm{mL}^{-1}\right)$.

\begin{tabular}{|c|c|c|c|c|c|c|}
\hline \multirow{2}{*}{$\frac{\text { DFPA }}{\text { Natural product/antifungal }}$} & \multicolumn{2}{|c|}{ C. albicans } & \multicolumn{2}{|c|}{ C. krusei } & \multicolumn{2}{|c|}{ C. tropicalis } \\
\hline & Alone & + DFPA & Alone & + DFPA & Alone & + DFPA \\
\hline DFPA & $\geq 1024$ & - & $\geq 1024$ & - & $\geq 1024$ & - \\
\hline Amphotericin b & $\geq 1024$ & $\geq 1024$ & $\geq 1024$ & $\geq 1024$ & $\geq 1024$ & $\geq 1024$ \\
\hline Mebendazole & $\geq 1024$ & $\geq 1024$ & $\geq 1024$ & $\geq 1024$ & $\geq 1024$ & $\geq 1024$ \\
\hline Nystatin & $\geq 1024$ & $\geq 1024$ & 64 & $\geq 1024$ & $\geq 1024$ & $\geq 1024$ \\
\hline Benzoilmetronidazole & $\geq 1024$ & $\geq 1024$ & $\geq 1024$ & $\geq 1024$ & $\geq 1024$ & $\geq 1024$ \\
\hline \multicolumn{7}{|l|}{ EEPA } \\
\hline Natural product/antifungal & Alone & + EEPA & Alone & + EEPA & Alone & + EEPA \\
\hline EEPA & $\geq 1024$ & - & $\geq 1024$ & - & $\geq 1024$ & - \\
\hline Amphotericin b & $\geq 1024$ & $\geq 1024$ & $\geq 1024$ & $\geq 1024$ & $\geq 1024$ & $\geq 1024$ \\
\hline Mebendazole & $\geq 1024$ & $\geq 1024$ & $\geq 1024$ & 64 & $\geq 1024$ & $\geq 1024$ \\
\hline Nystatin & $\geq 1024$ & $\geq 1024$ & 64 & 64 & $\geq 1024$ & $\geq 1024$ \\
\hline Benzoilmetronidazole & $\geq 1024$ & $\geq 1024$ & $\geq 1024$ & $\geq 1024$ & $\geq 1024$ & $\geq 1024$ \\
\hline
\end{tabular}

\begin{tabular}{|c|c|c|c|c|c|c|}
\hline \multicolumn{7}{|l|}{ HFPA } \\
\hline Natural product/antifungal & Alone & + HFPA & Alone & + HFPA & Alone & + HFPA \\
\hline HFPA & $\geq 1024$ & - & $\geq 1024$ & - & $\geq 1024$ & - \\
\hline Amphotericin b & $\geq 1024$ & $\geq 1024$ & $\geq 1024$ & 2 & $\geq 1024$ & $\geq 1024$ \\
\hline Mebendazole & $\geq 1024$ & $\geq 1024$ & $\geq 1024$ & 2 & $\geq 1024$ & $\geq 1024$ \\
\hline Nystatin & $\geq 1024$ & $\geq 1024$ & 64 & 1 & $\geq 1024$ & $\geq 1024$ \\
\hline$\underline{\text { Benzoilmetronidazole }}$ & $\geq 1024$ & $\geq 1024$ & $\geq 1024$ & $\geq 1024$ & $\geq 1024$ & $\geq 1024$ \\
\hline
\end{tabular}

\section{EFPA}

\begin{tabular}{lcccccc}
\hline Natural product/antifungal & Alone & + EFPA & Alone & + EFPA & Alone & + EFPA \\
\hline EFPA & $\geq 1024$ & - & $\geq 1024$ & - & $\geq 1024$ & - \\
Amphotericin b & $\geq 1024$ & $\geq 1024$ & $\geq 1024$ & 2 & $\geq 1024$ & $\geq 1024$ \\
Mebendazole & $\geq 1024$ & $\geq 1024$ & $\geq 1024$ & 0.5 & $\geq 1024$ & $\geq 1024$ \\
Nystatin & $\geq 1024$ & $\geq 1024$ & 64 & 64 & $\geq 1024$ & $\geq 1024$ \\
Benzoilmetronidazole & $\geq 1024$ & $\geq 1024$ & $\geq 1024$ & $\geq 1024$ & $\geq 1024$ & $\geq 1024$ \\
\hline
\end{tabular}

DFPA - dichloromethane fraction; EEPA - ethanol extract from the leaves; HFPA - hexane fraction; EFPA - ethyl acetate fraction 
Tintino S. R., Souza C. E. S., Guedes G. M. M., Costa J. I. V., Duarte F. M. et al.

glycosides are shown in the table 3. As observed with the antifungals, the natural products also demonstrated a MIC $\geq 1024 \mu \mathrm{g} \mathrm{mL}^{-1}$, but when the natural product was associated with the aminoglycosides, a synergistic or antagonistic antibiotic activity was detected against both bacterial strains assayed. When compared with the results of SUFFREDINI et al. (2006), the results observed on this work indicate a better antibacterial activity.

Tab. 3. Minimum inhibitory concentration (MIC) of antibiotics alone and associated with extract and fractions of Piper arboreum against Escherichia coli strain 27 and Staphylococcus aureus strain $358\left(\mu \mathrm{g} \mathrm{mL}^{-1}\right)$.

\begin{tabular}{lrrrrrr}
\hline DFPA & \multicolumn{2}{c}{ EC27 } & & \multicolumn{2}{c}{ SA358 } \\
\hline Natural product/antibiotic & Alone & + DFPA & & Alone & + DFPA \\
\hline DFPA & $\geq 1024$ & - & & $\geq 1024$ & - \\
Kanamycin & 1250 & 1250 & & 156 & 39 \\
Amikacin & 2500 & 2500 & & 78 & 78 \\
& & & & & 78 \\
Neomycin & 1250 & 1250 & & 78 & \\
Gentamicin & 156 & 625 & & 39 & 39 \\
\hline
\end{tabular}

\section{EEPA}

\begin{tabular}{lrrrc}
\hline Natural product/antibiotic & Alone & + EEPA & Alone & + EEPA \\
\hline EEPA & $\geq 1024$ & - & $\geq 1024$ & - \\
Kanamycin & 1250 & 1250 & 156 & 39 \\
Amikacin & 2500 & 625 & 78 & 78 \\
Neomycin & 1250 & 1250 & 78 & 78 \\
Gentamicin & 156 & 156 & 39 & 39 \\
\hline
\end{tabular}

\begin{tabular}{lrrrc}
\hline HFPA & & & & \\
\hline Natural product/antibiotic & Alone & + HFPA & Alone & + HFPA \\
\hline HFPA & $\geq 1024$ & - & $\geq 1024$ & - \\
Kanamycin & 1250 & $\geq 5000$ & 156 & 39 \\
Amikacin & 2500 & 78 & 78 & 78 \\
Neomycin & 1250 & 1250 & 78 & 78 \\
Gentamicin & 156 & 39 & 39 & 39 \\
\hline EFPA & & & & \\
\hline Natural product/antibiotic & Alone & + EFPA & Alone & + EFPA \\
\hline EFPA & $\geq 1024$ & - & $\geq 1024$ & - \\
Kanamycin & 1250 & 1250 & 156 & 39 \\
Amikacin & 2500 & 312 & 78 & 78 \\
Neomycin & 1250 & 1250 & 78 & 78 \\
Gentamicin & 156 & 39 & 39 & 39 \\
\hline
\end{tabular}

DFPA - dichloromethane fraction; EEPA - ethanol extract from the leaves; HFPA - hexane fraction; EFPA - ethyl acetate fraction 
All these different MIC results can be attributed to the environmental conditions related to the differences in the plants studied (CYSNE et al. 2005). However, the natural products of $P$. arboreum enhanced the antimicrobial activity of the assayed drugs, acting in a synergistic form (Tabs. 2, 3). This is the first report of synergism between natural products of $P$. arboreum and antimicrobial agents.

There are several mechanisms involved in the inhibition of microorganism growth, especially due to the hydrophobic nature of some phytocompounds. These compounds may interact with the lipid bilayer of the cell membrane, affecting the respiratory chain and the production of energy (WENDAKOON and SAKAGUCHI 1995) or enhancing the membrane permeability, including permeability to antimicrobials (BURT 2004). This permeability enhancement can be obtained from a combination of antimicrobial drugs with natural products in a sub-inhibitory concentration (CouTINHO et al. 2008, 2009b).

This strategy refers the usage of natural products and drugs in an approach with monoor multi-extract combinations that will affect not only a single but several targets (HEMAISWARYA et al. 2008, WAGNER et al. 2009).

\section{Conclusions}

As demonstrated in our work, natural products of Piper arboreum showed an expressive capacity to modulate the activity of antimicrobial drugs in a synergistic or antagonistic manner, representing an alternative to the efforts to control infectious diseases caused by multidrug-resistant strains of fungi and bacteria.

\section{References}

Agra, M. F., Freitas, P. F., Barbosa-Filho, J. M., 2007: Synopsis of the plants known as medicinal and poisonous in Northeast of Brazil. Brazilian Journal of Pharmacognosy 17, 114-140.

BURT, S., 2004: Essential oils: their antibacterial properties and potential application sin foods: A review. International Journal of Food Microbiology 94, 223-253.

CLSI - Clinical and Laboratory Standards Institute (2008). Performance standards of antimicrobial disk susceptibility test: Ninth Informational Supplement. NCCLS document M100-S9. National Committee for Clinical Laboratory Standards, Wayne, PA, 120126.

Coutinho, H. D. M., Cordeiro, L. D., Bringel, K. P., 2005: Antibiotic resitance of pathogenic bacteria isolated from the population of Juazeiro do Norte-Ceará. Revista Brasileira de Ciências da Saúde 9, 127-138.

Coutinho, H. D. M., Costa, J. G. M., Lima, E. O., Falcão-Silva, V. S., Siqueira-Júnior, J. P., 2009a: Herbal therapy associated with antibiotic therapy: Potentiation of the antibiotic activity against methicillin-resistant Staphylococcus aureus by Turnera ulmifolia L. BMC Complementary and Alternative Medicine 9, 13-17.

Coutinho, H. D. M., Costa, J. G. M., Lima, E. O., Falcão-Silva, V. S., Siqueira-Júnior, J. P., 2009b: In vitro interference of Hyptis martiusii Benth. and chlorpromazine against an 
Tintino S. R., Souza C. E. S., Guedes G. M. M., Costa J. I. V., Duarte F. M. et al.

aminoglycoside-resistant Escherichia coli. Indian Journal of Medical Research 129, $566-568$.

Coutinho, H. D. M., 2009: Factors influencing the virulence of Candida spp. West Indian Medical Journal 58, 160-163.

Coutinho, H. D. M., Costa, J. G. M., Siqueira Júnior, J. P., Lima, E. O., 2008: In vitro anti-staphylococcal activity of Hyptis martiusii Benth against methicillin-resistant Staphylococcus aureus-MRSA strains. Revista Brasileira de Farmacognosia 18, 670-675.

Cysne, J. B., Canuto, K. M., Pessoa, O. D. L., Nunes, E. P., Silveira, E. R., 2005: Leaf essential oils of four Piper species from the State of Ceará - northeast of Brazil. Journal of the Brazilian Chemical Society 16, 1378-1381.

Daferera, D. J., Ziogas, B. N., Polissou, M. G., 2003: The effectiveness of plant essential oils on the growth of Botrytis cinerae, Fusarium sp. and Clavibacter michiganensis subs. michignensis. Crop Protection 22, 39-44.

DANCER, S. J., 2001: The problem with cephalosporins. Journal of Antimicrobial Chemotherapy 48, 463-478.

Dignani, M. C., Solomkin, J. S., Anaissie, E., 2003: Candida. In: Anaissie, E., McGinnis, M. R., Pfaller, M. A. (eds), Medical mycology, 195-239. Churchill Livingstone, Philadelphia.

Gotlieb, O., 1981: New and underutilized plants in the Americas: Solution to problems of inventory through systematics. Interciencia 6, 22-29.

GeORgopapadakou, N. H., 2005: Infectious disease 2001: Drug resistance, new drugs. Drug Resistance Updates 5, 181-191.

GeISSMAn, T. A., 1963: Flavonoid compounds, tannins, lignins and related compounds. In: Florkin, M., Stotz, E. H. (eds), Pyrrole pigments, isoprenoid compounds and phenolic plant constituents. Elsevier Press, New York.

GiBBons, S., 2004: Anti-staphylococcal plant natural products. Natural Products Reports $21,263-277$.

Hughes, C., Muller, D., Hacher, J., Goebel, W., 1982: Genetics and pathogenic role of Escherichia coli haemolysin. Toxicon 20, 247-252.

Javadpour, M. M., Juban, M. M., Lo, W. C., Bishop, S. M., Alberty, J. B., Cowell, S. W., 1996: De novo antimicrobial peptides with low mammalian cell toxicity. Journal of Medicinal Chemistry 39, 3107-3113.

Konowalchuk, J., Dickie, N. S., Stavric, S., 1977: Vero response to a cytotoxin of Escherichia coli. Infection and Immunity 18, 775-779.

Nunes, J. D., Torres, G. A., Davide, L. C., Salgado, C. C., 2007: Citogenética de Piper hispidinervum e Piper aduncum. Pesquisa Agropecuária Brasileira 42, 1049-1052.

Nostro, A., Blanco, A. R., Cannatelli, M. A., Enea, V., Flamini, G., Morelli, I., 2004: Susceptibility of methicillin-resistant staphylococci to oregano essential oil, carvacrol and thymol. FEMS Microbiology Letters 230, 191-195.

Ramos, C. S., KATO, M. J., 2009: Hydrolysis of methyl benzoate from Piper arboreum by Naupactus bipes beetle. Journal of Brazilian Chemical Society 20, 560-563.

Regasini, L. O., Cotinguiba, F., Morandim, A. A., Kato, M. J., Scorzoni, L., Mendes, M. J., Bolzani, V. S., Furlan, M., 2009: Antimicrobial activity of Piper arboreum and 
Piper tuberculatum (Piperaceae) against opportunistic yeasts. African Journal of Biotechnology 12, 2866-2870.

RuIz, Q. J. R., RoQue, A. M., 2009: Antimicrobial activity of four plants from Peruvian north-east. Ciencia Investigativa 12, 41-47.

Salvagnini, L. E., Oliveira, J. R. S., Santos, L. E., Moreira, R. R. D., Pietro, R. C. L. R., 2008: Evaluation of the antibacterial activity of Myrtus communis L. (Myrtaceae) leaves. Revista Brasileira de Farmacognosia 18, 241-244.

Silva, M., Higino, J. S., Pereira, J. V., Siqueira-Júnior, J. P., Pereira, M. S., 2008: Antibiotic activity of the extract of Punica granatum Linn.over bovine strains of Staphylococcus aureus. Revista Brasileira de Farmacognosia 18, 209-212.

Simões, C. C., Araujo, D. B., Araújo, R. P. C., 2008: Study, in vitro and ex vivo, of the action of different concentrations of propolis extracts against microorganisms present in human saliva. Revista Brasileira de Farmacognosia 18, 84-89.

Scotland, S. M., Day, N. P., Willshaw, G. A., Rowe, B., 1980: Cytotoxic enteropathogenic Escherichia coli. Lancet 1, 90.

Suffredini, I. B., Paciencia, M. L. B., Varella, A. D., Younes, R. N., 2006: Antibacterial activity of Brazilian Amazon plant extracts. Brazilian Journal of Infectious Disease 10, 400-402.

Verhoeff, J., Beaujean, D., Vlok, H., BaArs, A., Meyler, A., Werkwn, V. D. C., 1999: A Dutch approach to methicillin-resistance Staphylococcus aureus. European Journal of Clinical Microbiology and Infectious Disease 18, 461-486.

WAGNER, H., UlRich-MerZENICH, G., 2009: Synergy research: approaching a new generation of phytopharmaceuticals. Phytomedicine 16, 97-110.

Wendakoon, C., SAKaguchi, M., 1995: Inhibition of amino acid decarboxylase activity of Enterobacter aerogenes by active components in spices. Journal of Food Protection 58, 280-283.

WHO - World Health Organization, 1998: Regulatory situation of herbal medicines: a worldwide review. WHO, Geneva. 